\title{
Stability of Outcrossing Rates in Eucalyptus globulus Seedlots
}

\author{
By M. H. McGowen ${ }^{1}$, D. R. Williams, B. M. Potts and R. E. Vaillancourt \\ Cooperative Research Centre for Sustainable Production Forestry and School of Plant Science, \\ University of Tasmania, Private Bag 55, Hobart, Tas 7001, Australia.
}

(Received $3^{\text {rd }}$ February 2004)

\begin{abstract}
Summary
Eucalyptus globulus has a mixed mating system and selfing leads to severe inbreeding depression. Thus, outcrossing rate is an important measure of seed quality in this species. Outcrossing rates were estimated on the frequency of a rare recessive chlorophyll deficient mutant in open pollinated seed. Variation of outcrossing rates across different flowering seasons, seed sizes and storage times was assessed in E. globulus seedlots. Although there was a significant difference between the trees studied, outcrossing rates within a tree were found to be stable across four flowering seasons and three seed sizes. Storage either on the tree or in the laboratory did not alter the outcrossing rate in a consistent manner. The stability of outcrossing rates with season of pollination, age and size of seed is noteworthy as these factors may vary widely in multi-tree seedlots used for plantation establishment.
\end{abstract}

Key words: Selfing, seed size, seed age.

\section{Introduction}

Eucalyptus globulus Labill. (sensu BRooker, 2000) is the premier Eucalyptus species for pulpwood plantations in many temperate countries around the world (ELDRIDGE et al., 1993). As it is often difficult to propagate the species vegetatively (TibBits et al., 1997), open pollinated seed orchards have been established for the production of improved seed. However, as these orchards rely on open-pollination, they can fail to produce high quality seed due to the mixed mating system of $E$. globulus. Although E. globulus is preferentially outcrossing, selfing is not uncommon and the outcrossing rates in $E$. globulus seed orchards have been reported to range from $77 \%$ (MoNCUR et al., 1995) to $92 \%$ (RUsSELl et al., 2001). Selfed progenies suffer significant inbreeding depression in growth and volume when compared to outcrossed progenies (HARDNER and POTTS, 1995). Because inbreeding depression can deleteriously affect productivity of plantations it is important to investigate the factors that may affect the outcrossing rate of E. globulus. For example, it has been observed in other serotinous species, including Eucalyptus delegatensis (MoRAN and BRown, 1980), Pinus contorta (HAMRICK, 1989) and Pinus banksiana (CHELIAK et al., 1985; SNYDER et al., 1985), that outcrossing rates have increased in seed that was retained longer on the tree. Such observations could be due to chance seasonal variation or the germination of selfed (or inbred) seed decreasing over time through seed aging.

Another major concern for plantation growers is the practise of segregating seed into size classes to improve uniformity in germination and seedling growth. Larger eucalypt seeds germinate faster, produce larger seedlings and show higher seedling survival rate (BALlONi et al., 1978; BATTAGLIA, 1993; BodEN, 1961; LOPEZ et al., 2003; MARTINS-CORDER et al., 1998; WATSON et al., 2001). However this has raised concerns that slower growth from smaller seed may reflect high levels of self-fertili-

$\overline{1) \text { Corresponding author. Email: mmcgowen@utas.edu.au }}$ sation which may affect growth later. Selfed seed has been found to be smaller in several other species with mixed mating system, including Dombeya acutangula ssp. acutangula (GIGORD et al., 1998), Banksia spinulosa (VAUGHTON and RAMSEY, 1997), Phormium tenax (CRAIG, 1989) and Hibiscus moscheutos (SNOw and SPIRA, 1993). The outcrossing rates of different seed size classes have not been examined previously in E. globulus.

The present study investigates the direct effect of season, size and seed age on outcrossing rates in E. globulus by comparing the frequency of albino progeny in seed samples from three separate harvests, with seed aged both on the tree and in the laboratory. While previous studies usually used allozyme markers to estimate outcrossing rates (CHELIAK et al., 1985; ELKASSABY et al., 1993; MorAN and BRown, 1980; SNYDER et al., 1985), this study used a single locus morphological marker. The marker was identified by PATTERSON et al. (2000) in two E. globulus trees that carry mutations in separate genes, which result in chlorophyll deficient seedlings when the mutation is homozygous. This marker is expressed at the cotyledonary stage, which enables a quick and easy estimate of the outcrossing rate from the deviation of the proportion of the albino germinants from a one to three ratio. This method allows large sample sizes to be screened for outcrossing rate and has been shown to be consistent with multi-locus isozymes estimates not only in E. globulus (PAtTerson et al., 2000) but also in Pinus ponderosa (MitTon et al., 1981).

\section{Materials and Methods \\ Seed collection and germination}

Open pollinated seed was collected from two trees located in remnant native stands on farmland in southern Tasmania (tree numbers 309 and 513), that were used in the study of chorophyll mutant inheritance by PATTERson et al. (2000). Seed was collected in 2000, 2001 and 2002. One and two year old capsules were randomly harvested from around the lower canopy of each tree. Thus seed was available from 1998, 1999, 2000 and 2001 flowering seasons since seed takes one year to mature in this Eucalyptus species. Capsules from each tree, harvest and flowering year combination were air dried as separate lots and then the seed removed from the capsules and sieved into three size fractions greater than $1.7 \mathrm{~mm}, 1.7 \mathrm{~mm}$ to $1.4 \mathrm{~mm}$, and $1.4 \mathrm{~mm}$ to $1 \mathrm{~mm}$. Within a month of harvest, the seedlots were sub-sampled and seed germinated in order to assess the frequency of chlorophyll mutants. In years 2000 and 2001 excess seed was stored and used in germination experiments of subsequent years to examine the effects of storage in ambient conditions.

For germination, samples of each seedlot were arranged in a randomised block design with each seedlot being represented by 2 to 9 replicates depending on seed availability. The seed sown from the last two years harvests was counted to allow for germination rate estimates. The seed sample from a given seedlot was evenly spread on the surface of potting mix in a seed punnet, and the punnet constituted the plot in the experi- 
mental design. The punnets were randomly arranged on $28^{\circ} \mathrm{C}$ heat beds in a glasshouse. Watering was provided by overhead misting, with the air temperature unregulated. Punnets were lightly sprayed with $1 \mathrm{gL}^{-1}$ of a benlate fungicide solution. Punnets were monitored regularly and scored for normal (green) or albino (yellow-pink) germinants with fully expanded cotyledons for up to 40 days following sowing. The seed from the 2002 harvest was spread evenly across the surface of vermiculite in sealable punnets and randomly arranged in a controlled growth cabinet at $25^{\circ} \mathrm{C}$ with 18 hours of light. Otherwise treatments were similar to previous years.

\section{Data analysis}

Frequencies of normal (green) seedlings and albino seedlings were calculated over all the experiments and replicates using the PROC FREQ procedure in SAS (version 8). Contingency $\chi^{2}$ tests were used to determine differences between the frequencies of green and albino seedlings between trees, seasons, size classes and storage times. Selfing rate was estimated using the proportion of albino seedlings in a punnet which was multiplied by four, based on the assumption that albinos are only produced by selfing (PATTERSON et al., 2000). Outcrossing was then calculated by subtracting the selfing rate from one and expressing it as a percentage. Significant variation in the frequency of the albino seedlings was assumed to represent significant variation in outcrossing rates.

\section{Results and Discussion}

The two trees differed significantly in their outcrossing rate $\left(\chi^{2}{ }_{1}=10.36 ; \mathrm{P}<0.0013\right)$. Tree 309 had a outcrossing rate of $48 \%$ and tree 513 had a outcrossing rate of $38 \%$ (averaged across all treatments). The low outcrossing rates are consistent with the collection of seed in the lower canopy which is known to have a lower outcrossing rate than seed collected in the upper canopy in self-compatible trees (PATTERSON et al., 2001). These outcrossing rates would be an indication of poor quality seed in forestry, but for our purpose they were ideal since they gave us scope for studying the factors that cause variation in selfing rate. The outcrossing rates were stable across flowering seasons for both trees (Table 1), with no significant differences found in the frequency of albinos between four seedlots for tree $309\left(\chi_{3}^{2}=3.12 ; \mathrm{P}<0.3736\right)$ and six seedlots for tree $513\left(\chi^{2}{ }_{5}=\right.$ 7.57; $\mathrm{P}<0.1813)$. The outcrossing rates across a number of flowering seasons and capsule ages have not been examined in Eucalyptus globulus previously, however it has been studied in two other eucalypt species, E. delegatensis (MoRAN and Brown,

Table 1. - Total number of seedlings, percentage of albinos and outcrossing rates for $E$. globulus seedlots collected from different age capsules from two different trees over three harvests.

\section{Total}

Harvest Flowering Seed number of \% Outcrossing

\begin{tabular}{ccccccc} 
Tree & year & season & age & seedlings & Albino & $\%$ \\
\hline 309 & 2000 & 1999 & 1 & 2844 & 13.3 & 46.8 \\
& & 1998 & 2 & 532 & 11.1 & 55.6 \\
& 2002 & 2001 & 1 & 603 & 12.4 & 50.2 \\
& & 2000 & 2 & 633 & 14.4 & 42.5 \\
& & & & & & \\
513 & 2000 & 1999 & 1 & 1642 & 15.2 & 39.4 \\
& & 1998 & 2 & 1818 & 15.3 & 38.8 \\
& \multirow{2}{*}{2001} & 2000 & 1 & 373 & 18.2 & 27.1 \\
& & 1999 & 2 & 1063 & 15.4 & 38.3 \\
& 2002 & 2001 & 1 & 645 & 18.1 & 27.4 \\
& & 2000 & 2 & 601 & 13.5 & 46.1 \\
\hline
\end{tabular}

1980) and E. stellulata (Brown et al., 1985). MoRAN and BRown (1980) found that the oldest of three seed crops of $E$. delegatensis had the highest outcrossing rate. In the study of E. stellulata eight seed crops were collected over three years. Temporal variation was found. One particular flowering season had a high selfing rate, and this decreased when the seed remained on the tree (BROwN et al., 1985).

Similar outcrossing rates have been determined for these same two trees (309 and 513) in previous studies. PATTERSON et al. (2000) used the proportion of albino progeny from the 1997 flowering season to calculate an outcrossing rate of $49.2 \%$ for tree 309 and $41 \%$ for tree 513 . Using isozymes, outcrossing was estimated to be $52 \pm 11 \%$ for tree 309 . The outcrossing rate of tree 309 was unchanged (49\%) for the 1998 season. This seasonal stability is unexpected as outcrossing rate in $E$. globulus was believed to be affected by both pollinator (MoNCuR et al., 1995) and flower abundance, two factors regarded as variable (HINGSTON, 2002). Although this study did not specifically monitor pollinator activity or flowering, the flowering years encompassed by this study included some of the lowest as well as the highest flowering seasons recorded in $E$. globulus trees in south-eastern Tasmania over a 18 year period (PAUl TILYARD, pers. com). Thus our results suggest that pollinator activity and flower abundance may have little effect on outcrossing rate of these two trees, rather the self-incompatibility level of a tree is probably the primary determinant of its outcrossing rate.

Storage under laboratory conditions had varied effects on outcrossing rates. The outcrossing rates of seed from tree 513 did not differ significantly $\left(\chi^{2}{ }_{2}=0.22 ; \mathrm{P}<0.8962\right)$, whether it had been left in the laboratory for one or two years (Table 2). However, the outcrossing rates increased significantly for tree 309 when the seed had been stored at room temperature in the laboratory for two years $\left(\chi_{2}^{2}=11.49 ; \mathrm{P}<0.0032\right)$. This was associated with a reduction in the germination from $87.9 \%$ after one year of storage to $80.7 \%$ after two years of storage. While the overall tests between seedlots collected on each tree (Table 1) showed no significant differences, the specific comparison of seedlots of tree 513 from the 1999 and 2000 flowering seasons which had been aged for an additional year on the tree did show a significant increase in outcrossing rate for the 2000 flowering season $\left(\chi^{2}{ }_{1}=4.01 ; \mathrm{P}<0.0452\right)$ but not the 1999 season $\left(\chi^{2}{ }_{1}=0.03 ; \mathrm{P}<0.8523\right)$. Seeds deteriorate during storage and eventually die due to aging (Wu et al., 1998) and it has been well documented that chromosomal aberrations and point mutations occur during seed storage (Roos, 1982). DNA repair has been suggested to occur in seeds stored in moist conditions only (ROBERTS, 1988), as repair is unlikely to occur in dry storage as normal metabolism is not possible. In each case where we obtained a significant difference in outcrossing rate with seed aging, our sample size was low, but this involved increased outcrossing rate. Aging effects on outcrossing rate

Table 2. - Total number of seedlings, percentage of albinos and outcrossing rate for $E$. globulus seedlots collected from two different trees and stored in laboratory conditions for one and two years.

\begin{tabular}{ccccc}
\hline & $\begin{array}{c}\text { Storage } \\
\text { time } \\
\text { Tree }\end{array}$ & $\begin{array}{c}\text { Total } \\
\text { (years) }\end{array}$ & $\begin{array}{c}\text { number of } \\
\text { seedlings }\end{array}$ & $\begin{array}{c}\text { Albino } \\
\text { Outcrossing } \\
\%\end{array}$ \\
\hline 309 & 0 & 2844 & 13.3 & 46.8 \\
& 1 & 918 & 12.3 & 50.8 \\
& 2 & 242 & 5.8 & 76.8 \\
513 & 0 & 1642 & 15.2 & 39.4 \\
& 1 & 1103 & 14.7 & 41.2 \\
& 2 & 209 & 15.8 & 36.8 \\
\hline
\end{tabular}


Table 3. - Total number of seedlings, percentage of albinos and outcrossing rate for $E$. globulus seedlots collected from two different trees in three seed size classes.

\begin{tabular}{ccccc}
\hline & $\begin{array}{c}\text { Size } \\
\text { Class } \\
\text { Tree }\end{array}$ & $\begin{array}{c}\text { Total } \\
\text { number of }\end{array}$ & $\begin{array}{c}\% \\
\text { seedlings }\end{array}$ & $\begin{array}{c}\text { Outcrossing } \\
\text { Albino }\end{array}$ \\
\hline 309 & $>1.7$ & 1563 & 13.2 & 47.0 \\
& $>1.4<1.7$ & 2589 & 12.8 & 48.7 \\
& $>1<1.4$ & 460 & 13.9 & 44.4 \\
513 & $>1.7$ & 2301 & 15.7 & 37.2 \\
& $>1.4<1.7$ & 3382 & 15.8 & 37.0 \\
& $>1<1.4$ & 459 & 13.7 & 45.1 \\
\hline
\end{tabular}

require further study. Nevertheless from a practical perspective, any commercial benefit gained from improved outcrossing rate in aged seed would be countered by the negative effects of reduced germination on nursery profitability.

Outcrossing rate did not differ significantly between the three different size classes in either tree (Table 3; tree $309 \chi_{2}^{2}=$ $0.47 ; \mathrm{P}<0.7915$ and tree $\left.513 \chi^{2}{ }_{2}=1.3 ; \mathrm{P}<0.521\right)$. Nurseries normally segregate $E$. globulus seed into different seed sizes to promote even germination and seedling growth (WATSON et al., 2001). As previously mentioned this practise based on research that has found that larger seeds germinate faster and better, produce larger seedlings and show a higher seedling survival rate. However there are concerns that slower growth from smaller seed may reflect high levels of self-fertilisation which may affect growth later. A previous study examined the genetic diversity of three size classes of seeds in Eucalyptus globulus using isozymes and found that the smallest seeds had the lowest fixation index which would indicate less inbreeding (MARTINS-CORDER et al., 1998). It was suggested that this could be due to higher mortality of selfed progenies in the small seed class. However, this is inconsistent with our results and those of HARDNER and POTTS (1995). While artificially selfed seed did have a higher percentage of inviable seed (seed with flattened testa) than outcrossed seed in the latter study, the germination percentage and germination rate of the seed which was classified as viable did not differ with cross type. Thus our results are different to that of other species where it is has been observed that selfed seed can be smaller (CRAIG, 1989; VAUGHTON and RAMSEY, 1997).

In summary, this study suggests that there is no clear advantage or disadvantage in allowing seed to age on the tree, or under laboratory conditions for a few years. Outcrossing rate appears to be stable across seasons, suggesting seed producers can collect seed whenever it is required and it can then be segregated into separate seed size classes to ensure more even germination. The smallest seed class can still be used by nurseries, after discounting for low germination rate, as its outcrossing rate is likely to be the same as that of the larger seeds.

\section{References}

Balloni, E. A., Kageyama, P. Y. and Corradini, L.: Efeito do tamanho da semente de Eucalyptus grandis sobre o vigor das mudas no viverio e no campo. Silvicultura 14, 41-43 (1978). - BATTAGLIA, M.: Seed germination physiology of Eucalyptus delegatensis R.T. Baker in Tasmania. Aus tralian Journal of Botany 41, 119-136 (1993). - BoDEN, R. W.: Australian studies on Eucalyptus seed 1956-61, with particular reference to germination behaviour. In: 'Second World Eucalyptus Conference'. Sao Paulo, Brazil pp. 596-603 (1961) - BROOKER, M. I. H : A new classification of the genus Eucalyptus L'Her. (Myrtaceae). Australian Systematic Botany 13, 79-148 (2000). - Brown, A. H. D., BARRETT, S. C. H. and MORAN, G. F: Mating system estimation in forest trees: models, methods and meanings. In: 'Population Genetics in Forestry'. (Ed. H. R. GREGORIUS) pp. 32-49 (Springer-Verlag: New York) (1985). - CHELIAK, W. M., Dancik, B. P., Morgan, K., Yeh, F. C. H. and Strobeck, C.: Temporal variation of the mating system in a natural population of Jack pine. Genetics 109, 569-584 (1985). - CRAIG, J. L.: A differential response to self pollination: seed size in Phormium. New Zealand Journal of Botany 27, 583-586 (1989). - EldRIDGE, K., DAVIDSON, J., HARwoOD, C. and VAN WYK, G.: 'Eucalypt Domestication and Breeding.' (Clarendon Press: Oxford) (1993). — El-Kassaby, Y., MEAgheR, M. D. and DavidSON, R.: Temporal variation in the outcrossing rate in a natural stand of Western White Pines. Silvae Genetica 42, 131-135 (1993). — GIGORD, L., Lavigne, C. and Shykoff, J. A.: Partial self-incompatibility and inbreeding depression in a native tree species of La Reunion (Indian Ocean). Oecologia 117, 342-352 (1998). - HAMrICK, J. L.: Isozymes and the analysis of genetic structure in plant populations. In: 'Isozymes in Plant Biology'. (Eds. D. E. SolTis and P. S. Soltis) pp. 87-105. (Dioscorides Press: Portland, Oregon) (1989). - HARdner, C. M. and PotTs, B. M.: Inbreeding depression and changes in variation after selfing Eucalyptus globulus subsp. globulus. Silvae Genetica 44, 46-54 (1995). Hingston, A. B.: Pollination Ecology of Eucalyptus globulus Labill. ssp. globulus and E. nitens (Deane \& Maiden) Maiden (Myrtaceae). PhD thesis, University of Tasmania (2002). - LoPez, G. A., PotTs, B. M., VAILLANCOURT, R. E. and APIOLAZA, L. A.: Maternal and carry-over effects on early growth of Eucalyptus globulus. Canadian Journal of Forest Research 33: 2108-2115 (2003). - Martins-Corder, M. P., Mori, E. S., CARVAlHo, M. T. V. and Derbyshire, E.: Genetic diversity of three size classes of seeds of Eucalyptus globulus ssp. globulus. Silvae Genetica 47, 614 (1998). - Mitton, J. B., Linhart, Y. B., Davis, M. L. and Sturgeon, K. B.: Estimation of outcrossing in Ponderosa Pine, Pinus ponderosa Laws., from patterns of segregation of protein polymorphisms and from frequencies of albino seedlings. Silvae Genetica 30, 117-121 (1981). Moncur, M.W., Mitchell, A., Fripp, Y. and Kleinschmidt, G. J.: The role of honey bees (Apis mellifera) in eucalypt and acacia seed production areas. Commonwealth Forestry Review 74, 350-354 (1995). Moran, G. F and Brown, A. H. D.: Temporal heterogeneity of outcrossing rates in alpine ash (Eucalyptus delegatensis R.T. Bak.). Theoretica and Applied Genetics 57, 101-105 (1980). - PATterson, B., VAILlanCOURT, R. E. and PotTs, B. M.: Eucalypt seed collectors: beware of sampling seedlots from low in the canopy! Australian Forestry 64, 139-142 (2001). - Patterson, B., Wolbang, C. M., Vaillancourt, R. E. and PotTs, B. M.: Inheritance of two chlorophyll mutants in Eucalyptus globulus. Silvae Genetica 49, 290-292 (2000). - RoBERTS, E. H.: Seed aging: the genome and its expression. In: 'Senescence and aging in plants'. (Eds. L. D. Nooden and A. C. LeOPOLD). (Academic Press Inc: London) (1988). - Roos, E. E.: Induced genetic changes in seed germplasm during storage. In: 'The Physiology and Biochemistry of Seed Development, Dormancy and Germination'. (Ed. A. A. KHAN) pp. 409434. (Elsevier: Amsterdam) (1982). - Russell, J., Marshall, D., GrifFIN, D., Harbard, J. and Powell, W.: Gene flow in South American Eucalyptus grandis and E. globulus seed orchards. In: 'Developing the eucalypt of the future. Proceedings of IUFRO International Symposium'. Valdivia, Chile pp. 149-150 (2001). — SNow, A. A. and SPIRA, T. P.: Individual variation in the vigor of self pollen and selfed progeny in Hibiscus moscheutos (Malvaceae). American Journal of Botany 80, 160 164 (1993). - SNyder, T. P., Stewart, D. A. and Strickler, A. F.: Temporal analysis of breeding structure in jack pine (Pinus banksiana Lamb.). Canadian Journal of Forest Research 15, 1159-1166 (1985). Tibbits, W. N., Boomsma, D. B. and JARvis, S.: Distribution, biology, genetics, and improvement programs for Eucalyptus globulus and E. nitens around the world. In: 'Proceedings of the $24^{\text {th }}$ Biennial Southern Tree Improvement Conference, June 9-12 1997'. (Eds. T. WHITE, D. Huber and G. Powell) pp. 1-15. (Southern Tree Improvement Committee: Orlando, Florida) (1997). - Vaughton, G. and Ramsey, M.: Seed mass variation in the shrub Banksia spinulosa (Proteaceae): resource constraints and pollen source effects. International Journal of Plant Sciences 158, 424-431 (1997). - Watson, M., Williams, D., Potts, B. and KRYGSMAN, M.: Seed quality and early seedling growth in Eucalyp. tus globulus. In: 'Developing the Eucalypt of the Future. IUFRO International Symposium'. (Ed. S. BARRos). (INFOR, Chile) p. 162 (2001). Wu, X. M., Wu, N. F., Qian, X. Z., Li, R. G., Huand, F. H. and Zhu, L.: Phenotypic and genotypic changes in rapeseed after 18 years of storage and regeneration. Seed Science Research 8, 55-64 (1998).

Herausgeberin: Bundesforschungsanstalt für Forst- und Holzwirtschaft: Schriftleitung: Institut für Forstgenetik und Forstpflanzenzüchtung, Siekerlandstrasse 2, D-22927 Grosshansdorf - Verlag: J. D. Sauerländer's Verlag, Finkenhofstrasse 21, D-60322 Frankfurt a. M. Anzeigenverwaltung: J. D. Sauerländer's Verlag, Frankfurt am Main.

Satz und Druck: Satz- und Grafikstudio König, Marburg — Printed in Germany. 
Rules for publishing a manuscript in Silvae Genetica can be requested from the publishing house or from the editorial office.

Silvae Genetica is an international journal, which continues Zeitschrift für Forstgenetik und Forstpflanzenzüchtung (Journal of Fores Genetics and Forest Tree Breeding) founded by W. LANGNER in 1951. In Silvae Genetica original articles, short notes, reviews, announcements and reports on meetings and congresses on Forest Tree Breeding and Genetics and related fields are published in German, English or French.

Reproduction of contributions is not permitted; reproduction of illustrations is permitted only with the approval of the author and the publisher.

Authors should send two copies of their manuscript to one of the regional co-editors, generally close to the institute from which the article originates. Authors are however free to select an appropriate co-editor who should be a native speaker of the language of the paper and familar with the subject matter.

Original articles, including tables, illustrations and literature must not exceed six printed pages (equivalent to 24 typed pages with 30 lines at double spacing and with a $5 \mathrm{~cm}$ border). Longer papers can only be accepted in exceptional cases. The same applies to extra costs for special plates. - In preparing the manuscript authors are asked to conform to the following arrangements. The title page should contain the following information: a) Title of the paper; b) Christian and surnames of the authors; c) Institute where the article has been written; d) if necessary, the present address of the authors as footnote; e) up to 10 key words to facilitate referencing of the paper; and on a separate special page; f) a summary in the original language of the paper and one in English, if that is not the original language of the paper.

For financial and technical reasons tables, figures and mathematical terms or formulae must be submitted separately from the text and ready for photoprinting. This applies especially to mathematical formulae which should be numbered and brought together in the finished state into one or few groups.

Manuscripts ready for printing will be registered the month they reach the editorial office in Grosshansdorf. They will be published in the order of their receipt. Their rearrangement for technical reasons is the prerogative of the editorial manager.

Short notes may be up to one page in length (about 4 pages of typescript) and should also be classified by some key words. They will be published as soon as possible.

Galley proofs of original articles and short notes will be sent to authors for correction. They must be returned with the least possible delay. The only corrections permitted are those arising during typesetting. No amendments of the manuscript are permitted. Corrections on announcements, reports, and reviews will be made in the editorial office.

Reprints: Authors obtain, free of charge, up to 30 reprints of their articles. Additional reprints may be purchased if ordered in advance from the publisher.

McGowen et al · Silvae Genetica (2004) 53-1, 42-44

Richtlinien zur Veröffentlichung eines Manuskriptes in Silvae Genetica können von der Redaktion oder dem Verlag angefordert werden.

Silvae Genetica ist eine internationale Zeitschrift; sie setzt die im Jahre 1951 von W. LANGNER begründete Zeitschrift für Forstgenetik und Forstpflanzenzüchtung fort. Silvae Genetica veröffentlicht Originalarbeiten, Kurzmitteilungen, Besprechungen sowie Hinweise und Berichte über Tagungen und Kongresse über Genetik und Züchtung sowie verwandte Fachgebiete in deutscher, englischer oder französischer Sprache, soweit sie für Forstgenetik und Forstpflanzenzüchtung von Bedeutung sind.

Der Nachdruck der Beiträge ist nicht gestattet; der Nachdruck von Abbildungen nur mit Genehmigung des Verfassers und des Verlages.

Manuskripte werden in zweifacher Ausfertigung im allgemeinen an einen der regionalen Mitarbeiter in der Nähe der Institution erbeten, aus der der Artikel stammt. Autoren sind jedoch frei, einen entsprechenden Mitarbeiter zur Durchsicht ihrer Arbeit zu wählen. Er sollte die Sprache, in der der Artikel abgefasst ist, als Muttersprache beherrschen und mit dem bearbeiteten Problem vertraut sein.

Originalarbeiten einschließlich Tabellen, Abbildungen und Literaturhinweisen sollen nicht über 6 Druckseiten hinausgehen. (Dieser Umfang entspricht ungefähr 24 Schreibmaschinenseiten mit 30 Zeilen mit doppeltem Abstand und $5 \mathrm{~cm}$ Rand). Längere Arbeiten können nur in Ausnahmefällen angenommen werden. Das gleiche gilt für spezielle Druck verfahren. - Die Anordnung der Manuskripte soll in der für Silvae Genetica üblichen Form geschehen. Die Titelseite soll die folgenden Informationen aufweisen: a) Titel der Arbeit, b) Vor- und Zunamen der Autoren, c) Institut, in dem die Arbeit entstanden ist, d) wenn notwendig, die gegenwärtige Anschrift der Verfasser als Fußnote, e) bis zu 10 Schlagworte zur Charakterisierung des Inhalts der Arbeit und zur leichteren bibliographischen Erfassung und außerdem auf besonderem Blatt, f eine Zusammenfassung in der Originalsprache der Arbeit und eine weitere in Englisch, wenn dies nicht die Originalsprache der Arbeit ist.

Aus finanziellen und technischen Gründen sollen Tabellen, Abbildungen und mathematische Ausdrücke oder Formeln getrennt vom Text als druckfertige Klischee-Vorlagen für den Photo-Druck eingereicht werden. Dies gilt besonders auch für im Text vorkommende mathematische Ausdrücke, die mit entsprechender Kennzeichnung (Nummerierung) in einer oder wenigen Klischee-Vorlagen zusammengefasst werden sollen.

Druckfertige Manuskripte werden mit dem Monat ihres Eingangs in die Schriftleitung in Grosshansdorf registriert und in der Reihenfolge ihres Eingangs veröffentlicht. Aus technischen Gründen kann der Redakteur jedoch eine andere Entscheidung treffen.

Kurzmitteilungen können bis zu einer Druckseite (etwa 4 Schreibmaschinenseiten) lang sein und sollten ebenfalls mit einigen Schlagworten charakterisiert werden. Sie erscheinen baldmöglichst außer der Reihe.

Druckfahnen von Originalarbeiten und Kurzmitteilungen werden den Autoren zur Korrektur zugesandt. Sie sollen unter Verwendung der international üblichen Symbole korrigier und möglichst umgehend an den Verlag zurückgeschickt werden. Dabei sind nur solche Fehler zu korrigieren erlaubt, die auf feh-
Des instructions pour publier un manuscrip dans Silvae Genetica peuvent être demandées à la rédaction ou à la maison d'édition.

Silvae Genetica est un Periodique international qui est la suite de Zeitschrift für Forstge netik und Forstpflanzenzüchtung (Journal of Forest Genetics and Forest Tree Breeding) fondé en 1951 par W. LANGNER et publie des articles originaux, en allemand, anglais ou français, ainsi que des Notes et des mises au point annonces et des compterendus de Réunions et de Congrès sur l'Amélioration des Arbres Forestiers, la Génétique et les disciplines voisines. La reproduction des articles n'est pas autorisée, la reproduction des illustrations n'est autorisée qu'avec l'approbation de l'auteur et de l'éditeur.

Les auteurs doivent envoyer deux exemplaires de leur manuscrit à l'un des co-éditeurs régionaux, en général le plus proche de l'Institut dont l'auteur de l'article fait partie. Toutefois, les auteurs sont libre de choisier un co-éditeur de même langue que celle de l'article, et à qui le sujet de l'article soit familier.

Les articles originaux y compris les tableaux, les figures et la bibliographie, ne doit pas dépasser 6 pages imprimées (soit 24 pages dactylographiées de 30 lignes, à double interligne et avec une marge de $5 \mathrm{~cm}$ ).

Les articles plus longs ne peuvent être acceptés que dans des cas exceptionnels. Les mêmes conditions s'appliquent aux frais supplémentaires pour les clichés spéciaux. Pour la préparation du manuscrit, il est demandé aux auteurs de se conformer aux indications suivantes: La page de titre doit contenir les informations suivantes a) Titre de l'article; b) Nom et prénoms des auteurs; c) Institut auquel l'auteur appartient; d) si nécessaire, l'adresse actuelle des auteurs en note infrapaginale; e) des mots clés permettant de faciliter la classification de l'article dans le limite de 10; et, sur une page séparée f) un résumé dans la langue originale de l'article - un résumé en anglais, si ce n'est pas la langue originale de l'article.

Pour des raisons financières et techniques les tableaux, les figures et les termes ou formules mathématiques doivent être présentésséparés du texte et prêts à l'impression-photo. Ceci s'applique particulièrement aux formules mathématiques qui doivent être numérotées, et rassemblées dans leur état définitif en un ou plusieurs groupes.

Les manuscrits prêts à l'impression seront enregistrès dans le mois de leur arrivée au Bureau de Rédaction de Grosshansdorf. Ils sont publiés dans l'ordre chronologique de leur arrivée au Bureau de Rédaction. Le Rédacteur peut toutefois modifier cet ordre pour des raisons techniques.

Les notes peuvent avoir jusqu'a 1 page (environ 4 pages dactylographiées) et doivent être indexées par quelques mots clés. Elles seront publiés aussi rapidement que possible.

Les épreuves d'imprimerie des articles originaux et des notes seront envoyées aux auteurs pour correction. Elles doivent être retournées dans le délai le plus bref possible. Les seules corrections permises sont celle qui ont rapport à la typographie. Aucune modification du manuscrit n'est pas permise. Les corrections des annonces, compte-redus et misses au point sont fait dans le Bureau de Rédaction. 
Publication schedule: 6 numbers each year.

Subscription: Silvae Genetica may be ordered through book-sellers in Germany and other countries, or directly from the publisher. Subscriptions are effective for a complete volume and continue in force unless terminated following delivery of the last number of a volume.

Price of subscription for the 6 numbers of a volume, $€ 248.00$; for students $€ 198.40$; postal expenses are extra.

This journal is covered by Biological Abstracts, Biosciences Information Service of Biological Abstracts (Series Agriculture, Biology and Environmental Sciencies) of Institute for Scientific Information, Forestry Abstracts, Institute for Scientific Information of the Academy of Sciences of Russia, Cambridge Scientific Abstracts.

Advertisements: Inquiries about the size and price of advertisements should be addressed to the publisher.

McGowen et al. Silvae Genetica (2004) 53-1, 42-44

lerhaften Satz zurückzuführen sind. Änderungen des Manuskripts sind nicht gestattet. Die Korrekturen von Ankündigungen, Berichten und Besprechungen werden in der Schriftleitung durchgeführt.

Sonderdrucke: Die Verfasser erhalten von ihren Arbeiten bis zu 30 Sonderdrucke kostenlos. Bei rechtzeitiger Bestellung bestehen für weitere Sonderdrucke Bezugsmöglichkeiten gegen Berechnung.

Erscheinungsweise: 6 Hefte im Jahr.

Bezugsmöglichkeiten: Silvae Genetica kann durch den in- und ausländischen Buchhandel oder direkt vom Verlag bezogen werden. Das Abonnement läuft weiter, wenn nicht unmittelbar nach der Lieferung des Schlussheftes eines Bandes eine Abbestellung erfolgt.

Bezugspreis für die 6 Hefte des Bandes beträgt $€ 248,00$ (für Studenten $€ 198,40$ ) zuzüglich Versandspesen.

Anzeigen: Anfragen über Preise und Größe von Anzeigen werden an den Verlag erbeten.
Tiré à part: Les auteurs peuvent obtenir gratuitement jusqu'aux 30 tirés à part de leur article. Les quantités supplémentaires peuvent être achetées par commonde à l'avance auprès de l'éditeur.

Périodicité de publication: 6 fasicules par an.

Abonnement: On peut s'abonner à Silvae Genetica auprès des libraires en Allemagne ou dans les autres pays, ou bien directement auprès de l'éditeur. L'abonnement est valable pour un volume complet, et se poursuit automatiquement, à moins que l'abonné ne demande qu'il se termine après le dernier numéro du volume en cours.

Prix de l'abonnement: pour les 6 numéros d'un volume: $€ 248,00$; pour les étudiants: $€ 198,40$. Les frais d'expédition sont en sus.

Publicité: Les demandes d'informations concernant les prix et la dimension des annonces publicitaires doivent être adressées à l'éditeur.

Publishing House/Verlag/Maison d'Edition: J. D. Sauerländer's Verlag

Finkenhofstr. 21, D-60322 Frankfurt am Main

Germany/Bundesrepublik Deutschland/République fédérale d'Allemagne

Tel.: +49/69/55 5217 · Fax: +49/69/5 964344

e-mail: J.D.Sauerlaenders.Verlag@t-online.de

Beilagen-Hinweis: Index Vol. 52, 2003

Diesem Heft liegen Titelblatt, Inhaltsverzeichnis und Register des Bandes 52 (2003) der Silvae Genetica bei. 